\title{
Perlindungan Hukum Bagi Nasabah Atas Tindakan Fraud yang Dilakukan Pegawai Bank
}

\author{
Audita Cindanufaza \\ Universitas Indonesia \\ auditacindanu@yahoo.com
}

\begin{abstract}
Abstrak. Bagi dunia perbankan, keberlangsungan perusahaan sangat bergantung dari pelayanan yang diberikan kepada masyarakat. Hal ini berarti, hilangnya kepercayaan dari masyarakat (nasabah) kepada bank akan berdampak buruk bagi keberlangsungan kegiatan bank. Kepercayaan rakyat untuk bank tidak terlepas dari peran personil atau pegawai bank. Peran dari personil atau pegawai bank, antara lain menghimpun dana dari masyarakat, menyalurkan dana kepada masyarakat, dan melakukan tugas dalam rangka menjalankan jasa perbankan. Walaupun pola dan perilaku pegawai bank dalam menjalankan tugasnya telah diatur, namun saat ini, masih banyak terjadi fraud yang dilakukan oleh pegawai bank. Bank yang seharusnya mengelola bisnis dengan kepercayaan telah banyak disalahgunakan oleh para pegawai bank yang dapat menimbulkan kerugian, baik bagi nasabah, pegawai bank itu sendiri, maupun bank yang bersangkutan. Dengan adanya fraud yang dilakukan oleh pegawai bank, maka bank dan pemerintah telah membuat beberapa pengaturan dengan tujuan memberikan perlindungan hukum terhadap nasabah. Dalam rangka penguatan sistem pengendalian intern Bank dan sebagai pelaksanaan lebih lanjut Peraturan Bank Indonesia Nomor 5/8/PBI/2003 tanggal 19 Mei 2003 tentang Penerapan Manajemen Risiko bagi Bank Umum serta mempertimbangkan terungkapnya berbagai kasus Fraud di sektor perbankan yang merugikan nasabah dan/atau Bank maka perlu diatur ketentuan mengenai penerapan strategi anti Fraud bagi Bank Umum.
\end{abstract}

\section{Kata Kunci: Bank, Pegawai Bank, Fraud}

\section{PENDAHULUAN}

Era globalisasi menjadikan peranan bank sebagai salah satu lembaga jasa keuangan menjadi sangat dibutuhkan oleh masyarakat di suatu negara. Lembaga perbankan juga mempunyai peran strategis dalam pembangunan nasional dan penunjang perekonomian dalam rangka mewujudkan masyarakat yang adil dan makmur sesuai dengan amanat pancasila dan UndangUndang Dasar Negara Republik Indonesia tahun 1945. Bank menurut pasal 1 angka 1 Undang-Undang Nomor 10 Tahun 1998 tentang Perubahan Atas Undang-

Undang Nomor 7 Tahun 1992 tentang Perbankan (yang selanjutnya akan disebut sebagai UU Perbankan) menyebutkan bahwa Bank adalah badan usaha yang menghimpun dana dari masyarakat dalam bentuk simpanan dan menyalurkan kepada masyarakat dalam bentuk kredit dan atau bentuk-bentuk lainnya dalam rangka meningkatkan taraf hidup rakyat banyak. Untuk itu setiap bank perlu terus menjaga kesehatannya dengan tetap memelihara sekaligus mempertahankan kepercayaan masyarakat kepadanya.

Dalam Undang-Undang No. 10 Tahun 1998 Pasal 4 tentang Perbankan dijelaskan bahwa "Perbankan Indonesia bertujuan menunjang pelaksanaan pembangunan ekonomi dan stabilitas nasional ke arah peningkatan kesejahteraan rakyat banyak." Peranan penting dan strategi dari lembaga perbankan merupakan pembuktian bahwa lembaga perbankan adalah salah satu pilar utama bagi pembangunan ekonomi dan sebagai agent of development dalam menunjang pelaksanaan pembangunan nasional.

Memperhatikan peran lembaga perbankan yang demikian strategis dalam mencapai tujuan pembangunan nasional, terhadap lembaga perbankan perlu senantiasa terdapat pembinaan dan pengawasan yang efektif, dengan didasari oleh gerak landasan gerak yang kokoh agar lembaga perbankan di 
Indonesia mampu berfungsi secara efisien, sehat, wajar, dan mampu menghadapi persaingan yang bersifat global, mampu melindungi secara baik dana yang dititipkan ke bidangbidang yang produktif bagi pencapaian sasaran pembangunan, demikian berdasarkan konsideran Undang-Undang Nomor 10 Tahun 1998 Tentang Perbankan.

Regulasi bank dalam rangka menjalankan tugasnya diatur dalam Pasal 25 Undang-Undang Nomor 23 Tahun 1999 tentang Bank Indonesia sebagaimana telah diubah dengan Undang-Undang Nomor 3 Tahun 2004 tentang Perubahan atas UndangUndang Nomor 23 Tahun 1999 tentang Bank Indonesia (selanjutnya disebut UUBI) menyatakan bahwa, Bank Indonesia berwenang menetapkan ketentuan-ketentuan perbankan yang memuat prinsip kehatihatian. Selanjutnya, Pasal 26 Undang-Undang Bank Indonesia mengatakan bahwa Bank Indonesia berwenang:

1. Melakukan dan mencabut izin usaha bank;

2. Memberikan izin pembukaan, penutupan, dan pemindahan kantor bank;

3. Memberikan persetujuan atas kepemilikan dan kepengurusan bank; dan

4. Memberikan izin kepada bank untuk menjalankan kegiatan-kegiatan usaha tertentu.

Bagi dunia perbankan, keberlangsungan perusahaan sangat bergantung dari pelayanan yang diberikan kepada masyarakat. Hal ini berarti, hilangnya kepercayaan dari masyarakat (nasabah) kepada bank akan berdampak buruk bagi keberlangsungan kegiatan bank. Sehingga pelayanan kepada masyarakat (nasabah) merupakan faktor yang penting bagi berkembangnya institusi. Oleh karena kegiatan bank menyangkut uang masyarakat dan kepercayaan yang diberikan, maka setiap periode dilakukan penilaian tentang kesehatan suatu bank. Bagi bank yang dinyatakan tidak sehat untuk beberapa periode, maka disarankan untuk melaksanakan penggabungan dengan bank lainnya. Kegiatan perbankan yang didasarkan pada kepercayaan ini dilakukan oleh pegawai bank yang didukung oleh masyarakat.
Pegawai bank adalah semua pejabat dan karyawan bank. Pegawai bank adalah pejabat bank yang mempunyai wewenang dan tanggungjawab tentang hal-hal yang berkaitan dengan usaha bank yang bersangkutan.

Aktivitas perbankan yang pertama adalah menghimpun dana dari masyarakat luas dikenal dengan istilah di dunia perbankan adalah kegiatan funding. Pengertian menghimpun dana maksudnya adalah mengumpulkan atau mencari dana dengan cara membeli dari masyarakat luas. Penghimpunan dana dari masyarakat ini dilakukan oleh bank dengan cara memasang berbagai bentuk simpanan. Jenis simpanan yang dapat dipilih oleh masyarakat adalah seperti giro, tabungan, sertifikat deposit dan deposito berjangka. Agar masyarakat mau menyimpan uangnya di bank, maka pihak perbankan memberikan rangsangan berupa balas jasa yang akan diberikan kepada si penyimpan uangnya. Oleh karena itu, pihak perbankan harus memberikan berbagai rangsangan dan kepercayaan sehingga masyarakat berminat untuk menanamkan dananya.

Peran dari personil atau pegawai bank, antara lain menghimpun dana dari masyarakat, menyalurkan dana kepada masyarakat, dan melakukan tugas dalam rangka menjalankan jasa perbankan. Peran personil atau pegawai bank tersebut semakin penting jika dikaitkan dengan seksama. Pada hakikatnya, pengamanan dana yang dititipkan masyarakat kepada bank, sematamata berada pada personil atau pegawai bank (termasuk pimpinan dan komisarisnya). Istilah pegawai bank dalam dunia perbankan ini dikenal dengan sebutan bankir. Bankir adalah para pelaku usaha bank yang terdiri dari Komisaris, Direksi, Pemegang Saham dan Pegawai lainnya yang menjalankan aktivitas perbankan. Yang termasuk dalam pengertian pegawai ini adalah Teller, Customer Service, Personal Banker, Authorize Signer, SubBranch Manager, hingga Branch Manager. Keseluruhan pegawai tersebut mempunyai tugas sesuai dengan bidangnya masing-masing. Pegawai 
yang memiliki intensitas kedekatan yang cukup erat dengan nasabah adalah personal banker, yang merupakan seseorang yang bertugas untuk mempromosikan, memasarkan, dan menjual produk, juga menjaga dan memelihara dana nasabah dan memberikan solusi kepada nasabah tentang produk mana yang terbaik untuk keperluan nasabah yang bersangkutan.

Walaupun pola dan perilaku pegawai bank dalam menjalankan tugasnya telah diatur, namun saat ini, masih banyak terjadi penyimpangan yang dilakukan oleh pegawai bank. Bank yang seharusnya mengelola bisnis dengan kepercayaan telah banyak disalahgunakan oleh para pegawai bank yang dapat menimbulkan kerugian, baik bagi nasabah, pegawai bank itu sendiri, maupun bank yang bersangkutan. Terungkapnya berbagai kasus tindak pidana perbankan (fraud) pada sektor perbankan yang merugikan nasabah dan/atau Bank. Berdasarkan uraian diatas, maka penulis merumuskan 2 (dua) pokok permasalahan yaitu:

1. Bagaimana pengertian fraud dalam perbankan?

2. Bagaimana perlindungan hukum terhadap nasabah apabila terjadi fraud yang dilakukan oleh pegawai bank?

\section{METODE PENELITIAN}

Bentuk penelitian yang digunakan di dalam penelitian ini adalah penelitian yuridis normatif. Penelitian yuridis normatif, yaitu penelitian yang mengacu pada norma hukum yang terdapat dalam peraturan perundangundangan, serta norma-norma yang berlaku dan mengikat di masyarakat. Dalam rangka penelitian ini, Penulis memilih menggunakan tipe penelitian yuridis normatif dengan bersumber pada bahanbahan kepustakaan.

\section{PEMBAHASAN}

Tinjauan umum mengenai fraud dalam bidang perbankan

Berdasarkan Surat Edaran nomor 13/28/DPNP perihal penerapan strategi antifraud bagi bank umum menjelaskan pengertian fraud adalah tindakan penyimpangan atau pembiaran yang sengaja dilakukan untuk mengelabui, menipu, atau memanipulasi bank, nasabah, atau pihak lain, yang terjadi di lingkungan bank dan/ atau menggunakan sarana bank sehingga mengakibatkan bank, nasabah, atau pihak lain menderitakerugian dan/ atau pelaku fraud memperoleh keuntungan keuangan baik secara langsung maupun tidak langsung.

Sedangkan definisi fraud menurut Black Law Dictionary ialah "1. A knowing misrepresentation of the truth or concealment of a materialfact to induce another to act to his or her detriment; is usual a tort, but in some cases (esp. When the conduct is willful) it may be a crime, 2. A misrepresentation made recklessly without belief in its truth to induce another person to act, 3. A tort arising from knowing misrepresentation, concealment of material fact, or reckless misrepresentation made to induce another to act to his or her detriment." (1. Kesengajaan atas salah pernyataan terhadap suatu kebenaran atau keadaan yang disembunyikan dari sebuah fakta material yang dapat mempengaruhi orang lain untuk melakukan perbuatan atau tindakan yang merugikannya, yang biasanya berupa kesalahan namun dalam beberapa kasus (khususnya dilakukan secara disengaja) merupakan suatu kejahatan: 2. Penyajian yang salah/keliru (salah pernyataan) yang secara ceroboh/ tanpa perhitungan dan tanpa dapat dipercaya kebenarannya berakibat dapat mempengaruhi/ menyebabkan orang lain bertindak/ berbuat; 3. Suatu kerugian yang timbul sebagai akibat diketahui keterangan/ penyajian yang salah (salah pernyataan), penyembunyian fakta material, atau penyajian yang ceroboh/tanpa perhitungan yang mempengaruhi orang lain untuk berbuat atau bertindak yang merugikannya.)

Badan Pengawas Keuangan memberikan definisi fraud yaitu suatu tindakan yang bertujuan untuk menyembunyikan, menutupi, atau dengan cara yang tidak jujur lainnya melibatkan atau meniadakan suatu perbuatan atau membuat pernyataan yang salah dengan tujuan untuk mendapatkan keuntungan pribadi di bidang 
keuangan atau keuntungan lainnya atau meniadakan suatu kewajiban bagi dirinya dan mengabaikan hak orang lain. Fraud adalah pengelabuan, penipuan, atau suatu perbuatan curang yang dilakukan untuk memperoleh keuntungan material dengan cara memutarbalikkan kenyataan.

Dalam konteks perbankan, definisi fraud dapat dipersempit menjadi suatu tindakan menyimpang yang dengan sengaja dilakukan oleh pihak tertentu yang bertujuan untuk menguntungkan dirinya sendiri dengan cara yang tidak jujur seperti mengelabui, menipu, bertindak curang, dan melakukan tindakan yang tidak sesuai prosedur (bagi pihak internal bank) di lingkungan perbankan, baik dengan ataupun tidak dengan menggunakan sarana bank, yang berujung pada dideritanya kerugian oleh bank dan pihak-pihak yang terkait dengan bank tersebut. Jadi, secara umum dapat disimpulkan bahwa fraud memiliki unsurunsur sebagai berikut:
1. Adanya
yang

keliru/pengelabuan

2. Adanya usaha penyembunyian

3. Menyangkut fakta material

4. Dilakukan secara sengaja

5. Untuk menguntungkan diri sendiri secara langsung maupun tidak

6. Mengakibatkan kerugian.

\section{Perlindungan Hukum Bagi Nasabah atas Perilaku Fraud Pegawai Bank}

Hubungan antara bank dan nasabah didasari dengan suatu hubungan kontraktual. Di dalam hubungan kontraktual adanya hak dan kewajiban atas dasar perikatan yang timbul. Perjanjian penyimpanan merupakan salah satu sumber hubungan formal kontraktual antara bank dan nasabah, di dalamnya berisikan hak dan kewajiban masing- masing pihak. Berkaitan dengan perjanjian penyimpanan, sebagaimana telah di uraikan sebelumnya, bahwa terdapat di dalamnya rahasia bank yang wajib di jaga oleh bank kerahsiaannya. Hal demikian merupakan suatu kewajiban hukum bagi bank atas dasar perjanjian penyimpanan dengan nasabah dan merupakan ketentuan rahasia bank yang disyaratkan Undang-
Undang Perbankan dalam kegiatan usaha perbankan.

Dunia perbankan sangat tergantung pada nasabah yang akan menyimpan dananya di bank dan yang meminjam dana dari bank, karena nasabah merupakan salah satu faktor penting dalam bisnis perbankan. Untuk mendapatkan nasabah tersebut, diperlukan kepercayaan yang dapat dipertanggungjawabkan oleh bank terhadap nasabahnya. Dalam menjalankan aktivitasnya, bank harus bisa memberikan layanan nasabah yang prima, artinya bank harus memberikan pelayanan semaksimal mungkin agar nasabah merasa nyaman dan aman untuk menyimpan dananya di bank yang bersangkutan. Semakin baik layanan nasabah prima dari suatu bank, maka semakin banyak nasabah yang akan menyimpan dananya di bank yang bersangkutan. Pemberian layanan nasabah prima dari suatu bank kepada nasabah bisa dilakukan dengan menawarkan produk dan/atau aktivitas yang mencakup:

1. Produk dan/atau aktivitas tradisional perbankan yang memiliki fitur dasar sesuai karakteristik produk dan/atau aktivitas tersebut, seperti giro, tabungan, deposito, sertifikat deposito, kredit/pembiayaan, produk derivatif yang bersifat plain vanilla, bank garansi, dan trade finance; dan

2. Produk dan/atau aktivitas nontradisional perbankan, seperti structured product dan produk keuangan nonbank, seperti reksa dana dan bancassurance.

Seperti yang telah dijelaskan dalam latar belakang penulisan ini, Kegiatan perbankan yang didasarkan pada kepercayaan. Kegiatan ini dilakukan oleh pegawai bank yang didukung oleh masyarakat. Pegawai bank adalah semua pejabat dan karyawan bank. Pegawai bank adalah pejabat bank yang mempunyai wewenang dan tanggungjawab tentang halhal yang berkaitan dengan usaha bank yang bersangkutan.

Dalam dunia perbankan, salah satu hal yang paling penting adalah kepercayaan. Dengan adanya pelanggaran dan/atau 
kejahatan yang dilakukan oleh pegawai bank, maka bank dan pemerintah telah membuat beberapa pengaturan dengan tujuan memberikan perlindungan hukum terhadap nasabah.

Berkaitan dengan perlindungan hukum terhadap nasabah, Marulak Pardede mengemukakan bahwa dalam sistem perbankan indonesia, mengenai perlindungan terhadap nasabah penyimpan dana, dapat dilakukan melalui 2 (dua) cara, yaitu:

1. Perlindungan secara implisit (implicit deposit protection), yaitu perlindungan yang dihasilkan oleh pengawasan dan pembinaan bank yang efektif, yang dapat menghindarkan terjadinya kebangkrutan bank. Perlindungan ini yang diperoleh melalui: (1) peraturan perundangundangan di bidang perbankan, (2) perlindungan yang dihasilkan oleh pengawasan dan menjaga kelangsungan usaha bank sebagai sebuah lembaga pada khususnya dan perlindungan terhadap sistem perbankan pada umumnya, (4) memelihara tingkat kesehatan bank, (5) melakukan usaha sesuai dengan prinsip kehatihatian, (6) cara pemberian kredit yang tidak merugikan bank dan kepentingan nasabah, dan (7) menyediakan informasi risiko pada nasabah.

2. Perlindungan secara eksplisit (explicit deposit protection), yaitu perlindungan melalui pembentukan suatu lembaga yang menjamin simpanan masyarakat, sehingga apabila bank mengalami kegagalan, lembaga tersebut yang akan mengganti dana masyarakat yang disimpan pada bank yang gagal tersebut. Perlindungan ini diperoleh melalui pembentukan lembaga yang menjamin simpanan masyarakat. Sebagaimana diatur dalam Keputusan Presiden Republik Indonesia Nomor 26 tahun 1998 tentang Jaminan Terhadap Kewajiban Bank Umum.

Meskipun perlindungan diatas sudah dilakukan, namun hingga saat ini masih banyak terdapat penyimpangan yang dilakukan oleh pegawai bank sebagai penghubung antara nasabah dengan Bank. Penyimpangan ini berkaitan dengan kejahatan yang terjadi dalam bidang perbankan. Kata "kejahatan" dan "tindak pidana" sering dikaitkan satu sama lain, namun pengertian tindak pidana lebih luas daripada kejahatan. Dalam Kamus Besar Bahasa Indonesia, kata "kejahatan" diartikan, antara lain "perilaku yang bertentangan dengan nilai-nilai dan normanorma yang berlaku yang telah disahkan oleh hukum tertulis (hukum pidana).

Fraud diartikan sebagai suatu tindakan penyimpangan atau pembiaran yang sengaja dilakukan untuk mengelabui, menipu, atau memanipulasi bank, nasabah, atau pihak lain, yang terjadi di lingkungan bank dan/atau menggunakan sarana bank sehingga mengakibatkan bank, nasabah, atau pihak lain menderita kerugian dan/atau pelaku fraud memperoleh keuntungan keuangan, baik secara langsung maupun tidak langsung.

Romli Atmasasmita menyatakan "Tindak Pidana Perbankan sering kali mengandung elemen-elemen kecurangan (deceit), penyesatan (misrepresentation), penyembunyian kenyataan (concealment of facts), manipulasi (manipulation), pelanggaran kepercayaan (breach of trust), akalakalan (subterfuge), atau penggelakan peraturan (ilegal circumvention) sehingga sangat merugikan masyarakat secara luas". Berdasarkan pernyataan ini tindakan fraud ini mengandung unsur-unsur:

1. Kecurangan yaitu pegawai bank melakukan kecurangan dengan cara mengambil dana nasabah yang seharusnya bukan miliknya.

2. Penyembunyian fakta, yang mana pegawai bank melakukannya dengan cara mentransfer uang nasabah kepada rekeningnya pribadinya, namun tidak tercantum di dalam buku tabungan nasabah. Ketika nasabah menanyakan uangnya kemana, pegawai bank tersebut akan beralasan adanya error system sehingga dana tidak tercantum di dalam buku nasabah, ataupun cara-cara lain 
yang dilakukan oleh pelaku untuk menyembunyikan fakta yang sebenarnya.

3. Memanipulasi data, dengan cara misalnya merubah nama nasabah menjadi orang lain (pihak ketiga diluar bank), yang mana pada akhirnya uang nasabah akan beralih pada pihak ketiga tersebut.

4. Pelanggaran kepercayaan, dalam hal ini pegawai bank jelas telah melakukan pelanggaran kepercayaan karena tidak bisa menjaga kepercayaan yang telah diberikan oleh nasabah tersebut.

Kasus Fraud oleh Pegawai Bank CIMB Niaga (Putusan No. 2819/Pid. Sus/2019/PN.SBY)

Salah satu kejahatan dalam dunia perbankan dikenal dengan istilah fraud. Salah satu contoh fraud yang terjadi di Indonesia, adalah seperti dalam Putusan No. 2819/Pid. Sus/2019/PN.SBY yaitu kasus penggelapan dana nasabah yang dilakukan oleh seorang Preferred Relation Manager CIMB yang bertugas menangani nasabah nasabah prioritas bernama Deky Kurnia Rahman (selanjutnya disebut Deky). Deky melakukan tindakan fraud kepada nasabah prioritas Bank CIMB yang bernama Dr. Soetojo. Peristiwa ini bermula pada tanggal 1 Februari 2017 Dr. Soetojo datang ke CIMB Niaga Cabang Jl. Dharmahusada (tempat kerja Deky) berencana untuk meminta rincian tagihan kartu kredit miliknya. Pada saat itu Deky menawarkan Dr. Soetojo untuk memperpanjang kembali tabungan MAPAN milik Dr, Soetojo mengingat pada akhir Februari 2017 akan cari atau jatuh tempo. Saat Dr. Soetojo bersedia, Deky menggunakan kesempatan tersebut untuk memberikan blangko kosong/form instruksi perubahan (CIF) yang kemudian ditandatangani oleh Dr. Soetojo. Tanpa sepengetahuan Dr. Soetojo, blangko kosong/form instruksi perubahan (CIF) tersebut Deky isi dengan nomor rekening milik Dr. Soetojo dan nomor telepon milik Deky dengan tujuan melalui nomor telepon milik Deky tersebut, Deky akan menerima notifikasi dalam bentuk SMS yang berisikan
M-PIN dimana dengan M-PIN tersebut Deky akan leluasa untuk melakukan transaksi keuangan melalui internet banking pada bank CIMB Niaga dari rekening milik Dr. Soetojo. Setelah proses input dan approval selesai, pada tanggal 14 Februari 2017 Deky menerima notifikasi dalam bentuk SMS yang berisikan M-PIN dari sistem Bank CIMB Niaga dan kemudian Deky mulai melakukan transaksi internet banking dengan mengambil sejumlah dana milik Dr. Soetojo untuk kepentingan pribadi Deky antara lain untuk membayar hutang, membeli 1 unit apartemen di Dian Regency Apartment dan berbagai transaksi yang diambil Deky dari rekening Dr. Soetojo tanpa sepengetahuan dan seijin Dr, Soetojo dalam rentang waktu tanggal 14 Februari 2017 hingga 4 Desember 2017.

Berdasarkan kasus tersebut, Penuntut Umum menuntut Deky dengan dakwaan tunggal Pasal 49 Ayat (1) Huruf a UU No. 10 tahun 1998 tentang Perubahan atas UU No. 7 tahun 1992 tentang Perbankan, yang mengatur bahwa pegawai bank yang dengan sengaja membuat atau menyebabkan adanya pencatatan palsu dalam pembukuan atau dalam proses laporan maupun dalam dokumen, laporan transaksi atau rekening suatu bank diancam dengan pidana penjara sekurang-kurangnya 5 (lima) tahun dan paling lama 15 (lima belas) tahun serta denda sekurang-kurangnya Rp.10.000.000.000,00 (sepuluh miliar rupiah) dan paling banyak Rp.200.000.000.000,00 (dua ratus miliar rupiah).

Majelis Hakim memutus bahwa Deky terbukti memenuhi unsur dakwaan Penuntut Umum dengan pertimbangan:

- Unsur barangsiapa terpenuhi karena Deky merupakan orang yang dapat dimintakan pertanggungjawaban atas perbuatan yang dilakukan.

- Unsur Anggota Dewan Komisaris, Direksi, atau Pegawai Bank terpenuhi dengan fakta bahwa Deky Kurnia Rahman adalah pegawai Bank CIMB yang diangkat dengan Jabatan CIMB Preferred Relationship Manager 
terhitung efektif sejak tanggal 28 Februari 2014 dibuktikan dengan Surat No. 00075/HROB/HR/II/2014.

- Unsur dengan sengaja membuat atau menyebabkan adanya pencatatan palsu dalam pembukuan atau dalam proses laporan, maupun dalam dokumen atau laporan kegiatan usaha laporan transaksi atau rekening suatu Bank, terpenuhi dengan pertimbangan Deky sengaja menawarkan pada Dr. Soetojo untuk memperpanjang kembali tabungan MAPAN miliknya karena Deky memiliki maksud untuk menyodorkan blanko kosong CIF yang nantinya akan Deky gunakan untuk memasukkan nomor telepon milik Deky ke dalam sistem Bank CIMB untuk ditandatangani Dr. Soetojo. Kemudian setelah form tersebut sudah ditandatangani Dr. Soetojo, Deky mengisi dengan nomor telepon miliknya berikut nomor ATM milik Dr. Soetojo dengan tujuan Deky akan menerima notifikasi dalam bentuk SMS yang berisikan M-PIN dimana dengan M-PIN tersebut Deky akan leluasa melakukan transaksi keuangan melalui Internet Banking atas rekening milik Dr. Soetojo. Setelah Deky mendapatkan MPIN melalui SMS yang ia dapatkan, Deky melakukan berbagai transaksi keuangan dalam kurun waktu 14 Februari hingga 4 Desember yang dilakukan berkali-kali tanpa sepengetahuan Dr. Soetojo selaku pemilik rekening hingga jumlah kerugian yang diderita oleh Dr. Soetojo mencapai Rp 1.100.512.655,- (satu milyar seratus juta lima ratus dua belas ribu enam ratus lima puluh lima rupiah).

Dalam kasus diatas, perlindungan hukum yang diberikan kepada nasabah diterapkan dari sisi hukum perlindungan konsumen karena hubungan bank dan nasabah adalah hubungan pengusaha dengan konsumen, hukum perdata Indonesia, dan juga hukum pidana. Bentuk nyata dari perlindungan hukum yang diberikan tersebut adalah penggantian kerugian oleh Bank
CIMB kepada Dr. Soetojo, dan penjatuhan pidana kepada Deky berupa penjara selama 5 (lima) tahun dan denda sebesar $\mathrm{Rp}$ 10.000.000.000,- (sepuluh milyar rupiah) subsidair 2 (dua) bulan kurungan.

Penulis menilai pertimbangan dalam putusan yang dijelaskan diatas sudah tepat dan Penuntut Umum menggunakan Pasal 49 Ayat (1) Huruf a UU No. 10 tahun 1998 tentang Perubahan atas UU No. 7 tahun 1992 tentang Perbankan. Namun, slein pasal diatas, menurut Penulis, Deky juga dapat dikenakan Pasal 263 KUHP yang berbunyi:

"Barang siapa membuat surat palsu atau memalsukan surat yang dapat menimbulkan sesuatu hak, perikatan atau pembebasan hutang, atau yang diperuntukkan sebagai bukti daripada sesuatu hal dengan maksud untuk memakai atau menyuruh orang lain memakai surat tersebut seolah-olah isinya benar dan tidak dipalsu, diancam jika pemakaian tersebut dapat menimbulkan kerugian, karena pemalsuan surat, dengan pidana penjara paling lama enam tahun."

$$
\text { R.Soesilo dalam bukunya Kitab }
$$

Undang-Undang Hukum Pidana (KUHP) serta Komentar-Komentarnya Lengkap Pasal Demi Pasal menjelaskan mengenai Pasal 263 KUHP sebagai berikut:

1. Yang diartikan dengan surat adalah segala surat baik yang ditulis dengan tangan, dicetak, maupun ditulis memakai mesin tik dan lain-lainnya, termasuk kuitansi;

2. Memalsukan surat diartikan sebagai mengubah surat sedemikian rupa, sehingga isinya menjadi lain dari isi yang asli atau sehingga surat itu menjadi lain dari yang asli. Caranya bermacammacam, termasuk mengurangi, menambah, mengubah sesuatu dari surat itu, atau memalsu tanda tangan;

3. Perbuatan memalsukan surat tersebut harus dengan maksud akan menggunakan atau menyuruh orang lain menggunakan surat itu seolah-olah asli dan tidak dipalsu;

4. Penggunaan surat palsu itu harus mendatangkan kerugian, namun kerugian yang dimaksud tidak perlu sudah ada, sehingga baru kemungkinan saja akan 
adanya kerugian sudah cukup diartikan sebagai kerugian; dan

5. Yang dihukum tidak hanya memalsukan surat, namun juga secara sengaja menggunakan surat palsu. "Sengaja" berarti orang yang menggunakan harus mengetahui benar bahwa surat yang ia gunakan adalah palsu.

Unsur yang harus digarisbawahi yaitu penjelasan mengenai memalsukan surat. Memalsukan surat diartikan sebagai mengubah surat sedemikian rupa, sehingga isinya menjadi lain dari isi yang asli atau sehingga surat itu menjadi lain dari yang asli. Caranya bermacam-macam, termasuk mengurangi, menambah, mengubah sesuatu dari surat itu, atau memalsu tanda tangan. Dalam kasus Deky, blangko kosong/form instruksi perubahan (CIF) yang ditandatangani oleh Dr. Soetojo sebelumnya tidak berisikan info nomor rekening milik Dr. Soetojo serta nomor telepon milik Deky untuk kepentingan M-PIN. Setelah ditandatangani oleh Dr. Soetojo, form tersebut kemudian ditambahkan keterangan mengenai nomor rekening milik Dr. Soetojo serta nomor telepon milik Deky sehingga menurut penulis Deky telah menambahkan isi surat tersebut sehingga menyebabkan kerugian bagi Dr. Soetojo selaku pemilik rekening.

\section{Langkah Mengantisipasi Fraud}

Untuk menghindari terjadinya fraud seperti yang dijelaskan sebelumnya, bank dan pemerintah melakukan beberapa langkah untuk memberikan perlindungan hukum impisit bagi nasabah. Dalam rangka penguatan sistem pengendalian intern Bank dan sebagai pelaksanaan lebih lanjut Peraturan Bank Indonesia Nomor 5/8/PBI/2003 tanggal 19 Mei 2003 tentang Penerapan Manajemen Risiko bagi Bank Umum (Lembaran Negara Republik Indonesia Tahun 2003 Nomor 56, serta mempertimbangkan terungkapnya berbagai kasus Fraud di sektor perbankan yang merugikan nasabah dan/atau Bank maka perlu diatur ketentuan mengenai penerapan strategi anti Fraud bagi Bank Umum dalam suatu Surat Edaran Bank Indonesia, dengan pokok-pokok ketentuan sebagai berikut:

\section{a. Penerapan Manajemen Resiko}

2. Pengawasan Aktif Manajemen

3. Struktur Organisasi dan Pertanggungjawaban

4. Pengendalian dan Pemantauan

\section{b. Menerapkan Strategi Anti Fraud}

Strategi anti Fraud yang dalam penerapannya berupa sistem pengendalian Fraud, memiliki 4 (empat) pilar sebagai berikut:

1. Pencegahan

2. Deteksi

3. Investigasi, Pelaporan, dan Sanksi

4. Pemantauan, Evaluasi, dan Tindak Lanjut

\section{c. Pengaturan Mengenai Pelaporan dan Sanksi}

Dalam rangka memantau penerapan strategi anti Fraud, Bank wajib menyampaikan kepada Bank Indonesia, halhal sebagai berikut:

a. Strategi anti Fraud sebagaimana dimaksud pada angka III, paling lambat 6 (enam) bulan sejak berlakunya Surat Edaran Bank Indonesia ini.

b. Laporan penerapan strategi anti Fraud, setiap semester untuk posisi akhir bulan Juni dan Desember, paling lambat 10 (sepuluh) hari kerja setelah akhir bulan laporan, dengan format dan cakupan sebagaimana dimaksud dalam Lampiran 2. Laporan ini harus disampaikan terhitung sejak laporan posisi akhir bulan Juni 2012.

Setiap Fraud yang diperkirakan berdampak negatif secara signifikan terhadap Bank dan/atau nasabah, termasuk yang berpotensi menjadi perhatian publik, paling lambat 3 (tiga) hari kerja setelah Bank mengetahui terjadinya Fraud. Laporan dimaksud paling kurang memuat nama pelaku, bentuk penyimpangan/jenis Fraud, tempat kejadian, informasi singkat mengenai modus, dan indikasi kerugian. Pelaporan tersebut tidak mengurangi kewajiban Bank untuk melakukan langkah-langkah sesuai dengan strategi anti Fraud yang dimiliki. 


\section{KESIMPULAN}

Berdasarkan uraian yang telah dilakukan berdasarkan permasalahan dan pembahasan, maka dapat diambil kesimpulan sebagai berikut:

1. Dunia perbankan sangat tergantung pada nasabah yang akan menyimpan dananya di bank dan yang meminjam dana dari bank, karena nasabah merupakan salah satu faktor penting dalam bisnis perbankan. Untuk mendapatkan nasabah tersebut, diperlukan kepercayaan yang dapat dipertanggungjawabkan oleh bank terhadap nasabahnya. Dalam menjalankan aktivitasnya, bank harus bisa memberikan layanan nasabah yang prima, artinya bank harus memberikan pelayanan semaksimal mungkin agar nasabah merasa nyaman dan aman untuk menyimpan dananya di bank yang bersangkutan.

2. Penjatuhan pidana untuk kasus Deky dalam putusan nomor 2819/Pid. Sus/2019/PN.SBY sudah tepat namun menurut penulis akan lebih tepat jika dikumulatifkan dengan Pasal 263 KUHP tentang pemalsuan surat, karena tindakan Deky menambahkan isi blangko termasuk dalam memalsukan surat dan tindakan tersebut menyebabkan kerugian baik bagi Dr, Soetojo selaku pemilik rekening dan Bank CIMB selaku pihak Bank yang mengganti kerugian nasabahnya,

3. Untuk menghindari terjadinya fraud seperti yang terjadi dalam kasus putusan nomor 2819/Pid. Sus/2019/PN.SBY , bank dan pemerintah melakukan beberapa langkah untuk memberikan perlindungan hukum impisit bagi nasabah. Dalam rangka penguatan sistem pengendalian intern Bank dan sebagai pelaksanaan lebih lanjut Peraturan Bank Indonesia Nomor 5/8/PBI/2003 tanggal 19 Mei 2003 tentang Penerapan Manajemen Risiko bagi Bank Umum (Lembaran Negara Republik Indonesia Tahun 2003 Nomor 56, serta mempertimbangkan terungkapnya berbagai kasus Fraud di sektor perbankan yang merugikan nasabah dan/atau Bank maka perlu diatur ketentuan mengenai penerapan strategi anti Fraud bagi Bank Umum dalam suatu Surat Edaran Bank Indonesia, dengan pokok-pokok ketentuan yaitu penerapan manajemen resiko, penerapan strategi antifraud, dan adanya peraturan mengenai pelaporan dan sanksi.

\section{DAFTAR PUSTAKA}

\section{BUKU}

Atmasasmita, Romli. Pengantar Hukum Kejahatan Bisnis. Jakarta Timur: Prenada Media, 2003.

Ghazali, Djoni S. dan Rachmadi Usman. Hukum Perbankan. Cetakan Pertama. Jakarta: Sinar Grafika, 2010.

Guritno, T. Kamus Perbankan dan Bisnis. cet. Kedua. Yogyakarta: Gadjah Mada University Press, 1996, hlm. 125.

Harminto, Try Bagus. Tinjauan Yuridis atas Penerapan Strategi Anti Fraud bagi Bank Umum. Depok: Universitas Indonesia, 2012.

Jailani, Ahmad. Perlindungan Hukum Bagi Nasabah Terkait Dengan Rahasia Bank. Malang: Universitas Islam Malang, 2008.

Kasmir. Bank dan Lembaga Keuangan Lainnya. Jakarta: Raja Grafindo Persada, 2012.

Marpaung, Leden. Pemberantasan dan Pencegahan Tindak Pidana Terhadap Perbankan. Jakarta: Djambatan, 2003.

Mertokusumo, Sudikno. Mengenal Hukum (Suatu Pengantar). Yogyakarta: Liberty, 1991.

Permata, Gita. Tanggung Jawab Bank Atas

Pelanggaran Kerahasiaan Data Nasabah Oleh Pegawai Bank. Skripsi: Universitas Islam Indonesia, 2018.

Sasongko, Wahyu. Ketentuan-ketentuan Pokok Hukum Perlindungan Konsumen. Bandar lampung:Universitas lampung, 
2007.

Sembiring, Sentosa. Hukum Perbankan, Edisi Revisi. Bandung: Mandar Maju, 2012.

Soesilo, R. Kitab Undang-Undang Hukum Pidana (KUHP) serta KomentarKomentarnya Lengkap Pasal Demi Pasal. Jakarta: Politeia, 1995.

Sutedi, Adrian. Hukum Perbankan Tunjauan Pencucian Uang, Merger, Likuiditas dan Kepailitan. Jakarta: Sinar Grafika, 2006.

Tunggal, Amin Widjaja. Pemeriksaan Kecurangan: Fraud Auditing. Jakarta: Rineka Cipta, 1992.

\section{JURNAL}

Porta, R. La. Investor Protection and Corporate governance. Jurnal of financial Economics 58 (1 January) 2000.

Tiffany, Mutiara. Perlindungan Hukum Terhadap Nasabah Atas Tindakan/Perilaku Fraud yang Dilakukan oleh Pegawai Bank. Bandung: Jurnal Magister Ilmu Hukum Program Pascasarjana Universitas Katolik Parahyangan FH.UNISBA. VOL. XIII. NO. 1, MARET - AGUSTUS 2012.

\section{UNDANG-UNDANG}

Peraturan Otoritas Jasa Keuangan Nomor 57/POJK.03/2016 tentang Penerapan Manajemen Risiko pada Bank Umum yang Melakukan Layanan Nasabah Prima

Surat Edaran Nomor 13/28/DPNP/2011 tentang Penerapan Strategi AntiFraud bagi Bank Umum.

Undang-Undang Nomor 10 Tahun 1998 tentang Perubahan atas UndangUndang Nomor 7 Tahun 1992 tentang Perbankan. 